\title{
The Strategic Objectives and the Priorities of the Regional Cultural Policy in a Global Scenario of Uncertainty
}

\author{
Skulymovskaya Lyubov Grigoryevna \\ $\mathrm{PhD}$ in Sociology \\ Professor \\ The Tyumen State Institute of Culture \\ Russia \\ Pavlova Olga Dmitreevna \\ Candidate of Culturology \\ Department of Education Russia \\ Nikiforova Alina Aleksandrovna \\ Candidate of Culturology \\ Senior Lecturer \\ The Nizhnevartovsk State University \\ Nizhnevartovsk, the Tyumen region
}

\begin{abstract}
The article is devoted to the consideration of the cultural policy's role in the Russian Federation's development on the whole and the distinct region - the complex constituent entity - the Tyumen region. The strategic objectives and the priorities of the cultural policy taking into account the crisis conditions of contemporary society. It's noted that the technology of project management and target programmes are important tools for implementing the national cultural policy in the conditions of a global uncertainty. The experience of the cultural policy's implementation on the territory of the Tyumen region is demonstrated in the article. Thus, the main mechanism for carrying out the policy is the national programme "The Main Directions of the Tyumen Region's culture development" for the period up to the year 2020. Informatization of the branch, a distinctive cultural area creating and its integration into the cultural space of Russia and the world on the whole have become the priorities for the culture's promotion. Particular emphasis in the programme has been placed on improving the quality of cultural life for the population of the Tyumen region. There is a specific role for library network's development and reading promotion, involvement of the museums into the area of cultural tourism, theatre environment's development, etc. The scenarios of the Khanty-Mansiysky Autonomous Region - Yugra's development are observed.
\end{abstract}

Keywords: region, cultural policy, the Tyumen region, the Khanty-Mansiysky Autonomous Region - Yugra, tourism, project technology, and target programmes, innovations, the level of cultural life.

In contemporary geopolitical realities problems of cultural policy in the regional level continue to be of particular interest and importance to the majority of scholars and practitioners. Cultural policy aimed at maintenance and strengthening of Russian cultural potential, enhancing ethical and spiritual values of population is one of the most important components in social policy. In Russia there has been a change of emphasis from the federal to the regional level of the system of the State cultural policy and management of culture, delegating a range of responsibilities including cultural heritage sites, decrease in the levels of federal funding in the field of culture in recent years. Solution to the problem requires the State's focused activities in managing relations between different government levels (state, regional and local), encouraging the development of innovative approaches in management practice in the culture sector, formulating strategies and tactics of economic, social and cultural regional development of the Russian Federation. Russia is characterized by the wide diversity of territories, which vary in size, ethnic composition of the population, landscape, natural, climatic characteristics, folk traditions, rites, arts, crafts, trades and other components, composing uniqueness and cultural identity of the territory. 
The State cultural policy transforms into regional one because different natural, climatic and business conditions, historical and ethno-cultural specific features let create a wide range of shades of the local culture within the national culture. Therefore, a careful study of a significant influence on the culture, its functioning and evolution can't be successful without taking account the specific characteristics of a region. In the domestic scientific literature various approaches are used in examination and coping with the very essence of cultural policy. Versatility of the phenomenon should be stressed. From the point of view of A.Y. Fliyer, most of diverse cultural processes take place in society spontaneously only under the authority of self-organization of people and social activities underlying laws. However, individual components of the complex process follow targeting and reasonable regulation, promotion and drawdown of various ongoing tendencies in accordance with understanding and grasp of the strategies required for human civilization movement. "Cultural Policy" means the set of measures required to ensure management of values and spiritual dimensions of public life.[10, p. 108]. In particular, awareness and understanding of regional peculiarities of culture development are essential if effective regional cultural policy is to work out and taking into account cultural interests of the various actors in the implementation of the cultural policy is a basis for understanding. It's necessary to realize that the state and regions should be considered as the partners with the common aim of creating conditions for positive developments of cultural processes, focus on the creative vitality of peoples. [5, p.14].

N.A. Mikheeva considers that cultural policy is the activity, connected with formation and agreeing on social mechanisms, conditions of cultural activities of the population and all its groups, development-oriented and responsive to the cultural, creative, recreational needs. [5, p .9]. In the process of region's social-economic development formation of regional culture takes place. For Y.V. Hlyshchyova its specificity is that the regional culture is formed originally as the option, "the specific form of society and human existence in given spatial coordinates which is based on the historical tradition, shaping value system, and producing personality types. Undoubtedly, cultural peculiarities play very important part in the regional development and they tend to be brightly manifested during periods of crisis. The strategy of cultural development takes shape just on the regional level with due regard for specific social-economic features of region's development, its cultural capacity, various population groups' interests and requests. [11, p. 149]. According to I.Y.Murzina, methodological foundations of the regional cultural policy contain identification of priorities for cultural development on the basis of cultural life quality and existing problems; formulation or initiation of various socio cultural programmers in accordance with the priorities; the support of national bodies and realization of the programmes by means of a balanced allocation of resources: material, financial, staff and information. [6, p. 78].

In Russia existing understanding of regional cultural policy is based on the Concept of Regional Policy in the Russian Federation Modernization for the Period until the year 2020.According to the Concept, region is "a part of the territory of the Russian Federation, possessing a common system of natural, social-economic, cultural, national and other backgrounds. The region may coincide with territorial borders of the constituent entity of the Russian Federation, or it may be the part of it. The region also can combine the territories or the parts of some constituent entities of the Russian Federation.[4].

O.N.Astafyeva notes, on the one hand, defence of national unity, promotion of socio-cultural resources and development of the national culture as the whole; on the other hand, - a very wide range of innovations implement, developing long-term models for updating forms and modernization. She also indicates the need for talking about a set of similar objectives for strategic management in the field of culture. O.N.Astafyeva points out objectives, associated with the problems of equalization and maintaining a certain level of well-being and region cultural development, and also identity all regional population groups as the subject of self-development, understanding the value of their own local culture and opportunities for self-realization in conditions of modernization and a shift to innovative development approaches of the Russian Federation.[1]. O.N.Astafyeva considers, that long-term goals for regional development closely related to socio cultural activities should be determined by regional community and reflected by the representatives of the local authorities, social organizations, intellectual elite. The existence of long-term goals in the region should be evaluated as a positive factor to overcome the crisis. [1]. O.N.Astafyevaand V.S.Zhidkov are very similar in their approaches. So, he shares the point of view about cultural policy as a responsible option for long-term goals and priorities, the creation of mechanisms that facilitate their realization and focused resources. In general terms the prior aim of the cultural policy is the preservation and the transfer of cultural heritage to the next generations, the support of artistic creation and wide dissemination of various cultural forms for a wider audience. We ad here this definition of the cultural policy while the publication is being writing. [3, p. 47]. 
While agreeing on the interpretations mentioned above, there is basis to claim that contemporary approach to working out regional cultural policy aims, first of all, at the specific nature of the region historic development, traditional practices, national and multi-religious differences; infrastructural facilities - cultural institutions, mass media, human capacity in the light of a national historical and cultural context of the region. The objective of the cultural policy on the regional level is defined considering the importance of regions as large socio cultural centers having cultural differences and identities. Therefore, solution to socially significant problems on the regional level could characterize improving or worsening socio cultural situation in society at large. In the current context and a world order of sanctions in Russia it's necessary to work out and realize the support, which lets people, living in small and medium-sized towns, rural settlements to visit performances, concerts and exhibitions, to gain access to the best samples of professional arts. That is convergence among different levels of various regions' cultural development, ensuring equal opportunities for human development in the areas of cultural treasures: access to the benefits of cultural achievements, equal participation in cultural activities through cultural institutions taking into account regional, national, ethno-cultural aspects of people living in various parts of Russia and their cultural needs.

Russian cultural researchers O.N. Astafyeva and S.B.Sinetskiy conceptualize the key idea of the dialogue as a methodological basis of the contemporary cultural policy on the level of rural settlements: thus, cultural event as "ideal type" of citizens' leisure activities, localized in a modern area is the primary tool of the cultural policy. To provide the meaning of the dialogue strategies the authors suggest to apply to the key issue of a contemporary and adequate support and the considerable increase of approaches to the cultural policy, conceptualization of the characteristics of socio-cultural dynamics in the context of super-fast high-speed today's geopolitical realities, economic, technical-technological and other developments. Design and modelling of essential communication areas sure the transition from the theoretic level towards practical one is looked upon as the opportunity to stimulate interactions of various subjects of cultural policy. No doubt, in the current conditions successful projects have changed environment in many Russian settlements due to talent and creativity of people, living there. The complex analysis of regional socio-cultural practice shows that culture may become the source of the territory development, it's able to change people's attitude towards their settlement and to initiate personal participation in setting up areas for socio-cultural communications and celebrations carrying out. [2, p. 74 - 75]. Design technologies in the field of culture can be regarded as an important tool for national cultural policy realization in a global scenario of uncertainty. Targeted programmes as a tool of management and open social systems are widely implemented all over the world. Viability of the programmes depends on a balance of inside sources and external circumstances of development, their behavior fragile and unpredictable because of the strong impact of random uncertainties which can't be anticipated. Therefore, elaboration and realization of the comprehensive and targeted programmes impose restrictions on the system of management, issues special requirements for the system. Particularly, - need to take into account the multifaceted nature of these systems' development, and also the importance of creating qualitative backward linkages, flexible response to the change in the ratio between internal and external factors. The use of the focused programmes as an effective tool of social regional processes' management requires the development an appropriate organizational and economic mechanisms. It should be emphasized that identification of common features of organizational and economic mechanisms of their functioning contributes to the rationalization of the social processes' management and make it more effective, despite the specificity when developing particular social programmes. Besides, social programmes should play the leading role in the complex of focused programmes put in practice in the system of the modern Russian society's management. For it there is a need to rationalize the programmes and ensure their systemic application. Targeted programmes of economic, social and cultural developments of different regions play a crucial role in regulation of territorial and economic processes. Every programme is thus the agreed and tied to the resources, responsible persons, time frame for implementation; the complex of research, project, productive, social, organizationaleconomic and other target activities, realized by means of state support. The programmes ensure an effective solution of nationwide, inter-territorial and regional objectives in the field of economic, scientific and technological, social-cultural and ecological development of the region - constituent territories of the Russian Federation, economic area, zone, municipality, etc. The proposals to develop and achieve the regional targeted programmes directed on an effective promotion of a culture deserve particular relevance to the regions of Russia in the context of their modern novation relating to the regional cultural policy. The government programme "Main Directions for the Cultural Development of the Tyumen region for the period until 2020" is an implementation mechanism of the cultural policy in the Tyumen region. 
Its strategic objective is to meet the needs of the population in the area of cultural products and services. One of priority innovative areas is informatization of the branch, development of information and communication resources, creation of a single information and cultural area in the region, its integration into the All-Russian and global information societies. Upgrading of the information processes of culture takes place in all main directions of the branch development. The Tyumen region is one of the first constituent territories that have developed a unified regional cultural policy. Achieving the strategic goal is carried out through the implementation of the national and regional targeted programmes' activities and providing intergovernmental transfers to the budget of local authorities in the Tyumen region. The institutionalization of the regional cultural policy allowed for effective use of funds allocated to the municipal budgets under the agreed programmes. In addition, the Tyumen region is one of the first to define the citizen of the Tyumen region as the main priority of the regional cultural policy and ensuring the quality of life of citizens as the goal. The part of the process of informatization of the Tyumen region is informatization of libraries. The municipal libraries are the most requested and accessible cultural institutions, providing access to information, knowledge, cultural properties for the population. Therefore, information recourses of libraries have gained strategic importance that determines the level of social and economic development of the region. The Tyumen regional scientific Mendeleev's library based on the library of the regional center of the President Yeltsin's library that is a modern information and library center of high European level was reopened after being renovated, and that has contributed to serious progress on the promotion of library facilities including access to informational electronic resources. To realize the programme's task the Tyumen libraries continue systematic work to develop new forms of readers' engagement, dissemination of reading culture (organization of meetings with the authors, quests, creative laboratories, intellectual games, etc.)

The ongoing modernization of all branches of culture the role of the museums in preserving the cultural heritage and involving the population in various projects. To improve the quality of services provided by the museums of the Tyumen region and to attain an effective use of resources informatization of museum activities has become a priority area. Moreover, a set of projects to bring about adoption of modern information systems: digital museum library, interactive thematic expositions, virtual topical collections, computer installations, etc.) are realized in the region. The museums of the Tyumen region serve as a meaningful dominant of cultural tourism. They present the complex of objects to show, create information reasons, culture programmes, and activities for various focusgroups among visitors, develop attractive brands, shape new tour routs. Now the museums use synthesis of the various forms of mass cultural activities, introduce exciting contests, musical evenings, intellectual tournaments, film clubs, patriotic classes, museum lessons. The satisfaction of various population groups with the quality of social and recreational activities provided constitutes one of the important indicators of the social situation and population's quality of life in the region. Club-type cultural institutions as an essential element of the regional social infrastructure play a very important role in formingof the recreational preferences of the population. In support of the objective the implementation of activities aimed at developing regional theatres tours, quality philharmonic and theatre services delivery to the people is provided for. The Tyumen's dramatic stage was founded in the middle of nineteenth century and today it's the biggest in Russia. The modern building was designed in 2008 in classical style: its façade was decorated with the portico with the columns, statues and stucco work.

The Tyumen region as the whole of Russia is multi-ethnic and multicultural society, therefore, the work of cultural institutions presents its own specificities. The National Cultures Palace's main activity is cooperation with national social organizations and autonomies engaging in all areas of cultural and social activities of the region, also they develop communication with historic homelands, international communities, public associations on the regional, national and international levels. The purpose of cooperation is development of joint ethniccultural projects, taking part in regional and federal programmes which contribute to identification and stimulation of national public opinion's creative power and realization of their language, ethno-cultural rights. Shaping and development of the system of multiethnic and intercultural tolerance is ensured through the system of national holidays, creative evenings, lecture courses. There is another innovative component in realization of the cultural policy in the Tyumen region - the implementation of a system for monitoring the effectiveness of the sphere's development. It has been driven by the need of the institutions and the cultural authorities to get information about population's cultural needs and preferences, social and economic characteristics of the audience, motives of visiting, the degree of consumers' satisfaction and the quality of the services provided. The monitoring in the sphere of culture is a system of continuous observation, assessment of the real situation. The results let develop strategic planning and define priorities. 
The Tyumen region is the complex subject of the Russian Federation and it contains two autonomous areas: theKhanty-Mansiysky Autonomous Region - Yugra, the Yamal-Nenets Autonomous Region. These areas are independent members of the Russian Federation, oil and gas-rich regions. In the Strategy of Social and Economic Development of the Khanty-Mansiysky Autonomous Region to 2020 and for the period until 2030 the region's image as the unity of three spatial zones needed different cultural policies was formed for the first time. The creators of the program have emphasized the new possible all-Russian specialization of the Khanty-Mansiysky Autonomous Region - the area for the development in the North and in the Arctic region - and formulation of the Yugra's brand as the strategic center of these territories' development. [8]. In the context of global uncertainty various development scenarios for the Yugra can be observed: "The Window of Possibilities" - innovation scenario with a comparative advantage over other regions containing the accumulated technological, intellectual, financial potential. It's expected to make leap towards some new non-oil activities and to transform the region into the foothold for the development of the North and the Arctic.

1) "The Innovative Foothold" - according to the scenario oil and gas sector will have remained its core position in the economy of the region by the year 2030. Simultaneously, some alternative non-oil economy will have appeared. Certainly, it won't be comparable to the oil and gas industry according to the gross national product it's going to have effective indicators in the way of employment and the dynamics of development. Thus, the Khanty-Mansiysky Autonomous Region - Yugra as the Russian's largest economic entity should become the innovative foothold for the development of the Russian North.

There is another development path in the conditions of global uncertainty, reflected in the so-called Strategy 2030, - it's import substitution in all spheres of the economy including the regional fields of the culture and tourism. The sphere of the culture of the region develops according to the Strategy of the Development of Culture in the Khanty-Mansiysky Autonomous Region - Yugra for the period until the year 2030. The strategy comprises a general assessment of results achieved of the cultural development in the autonomous region, determines the system long-term objectives and goals, priorities and mainstream development providing raising the cultural level, improving the quality of life and living standards and principal mechanisms for carrying out the objectives.[9].

In the strategy culture is presented as the strategic resource of innovative performance, as a tool of the state cultural policy in the region covering all cultural activities, education in the field of culture, inter-ethnic relations, international humanitarian and cultural cooperation and also brining up citizens, forming civic and regional identity, information space across the region.

The strategy is intended to provide to ensure the key indicators of the cultural modernization (accessibility, quality, effectiveness) and to serve as a basis for the national programmes in the relevant area of the region, longterm and short-term projections of certain cultural areas' development and relevant legislative initiatives. In particular, the objective of the national programme of the Khanty-Mansiysky Autonomous Region - Yugra "The Development of the Culture and the Tourism in the Khanty-Mansiysky Autonomous Region - Yugra for 2016 2020 " is to preserve the cultural identity and to create conditions for ensuring equal access of cultural goods and services for the development and realization of the cultural and spiritual capacity. The maim priorities in the area of culture include preserving and development of cultural potential of the autonomous region, the system of artistic education, improvement of cultural infrastructure, material and technical resources, state protection of cultural heritage sites, archives. [12]. It must be noted that in recent years in the sphere of culture of the KhantyMansiysky Autonomous Region - Yugrasignificant change has taken place due to various factors such as new technologies and telecommunication. Radical change relates to the museums and library activities where modern science and technology, virtual space have been mastered. As for the technical equipment of the libraries and museums in the region is concerned the indicator is significantly higher than the Russian average. The museum network in the region has been characterized by growth of electronic resources (catalogues, virtual museums, exhibitions), the significant increase in the number of exhibitions, the development of the information database and free access to various global information resources.

The main course of professional performing arts in the autonomous region is equal delivery of quality concert and theatrical services to the population. Cinematograph in the region remains one of the dynamically developing, accessible, socially oriented and sought after cultural industries. Realization of the activities of the national programme is possible through attracting extra budgetary funds, contributions from donors, charitable donations for logistics in the field of culture. In the region considerable attention is paid to the development of domestic tourism, firstly, ethnographic and ecological. 
In accordance with the concept of promotion of domestic and inbound tourism in the Khanty-Mansiysky Autonomous Region - Yugra priorities of the tourist and recreational services aim at creating of competitive regional products and their promotion in the Russian market and international one. Infrastructure development in the tourist sector with a view to ensuring environmental security, protection of biodiversity and landscape diversity, safeguarding and sustainable use of the natural heritage is an area of critical importance. Need to adopt the concept depends on a number of factors: changes taking place at the foreign and local tourist markets, tourism's impact on economy and social sphere in the region, development of the cross-regional and international cooperation, requirements for the implementation of advanced technologies in the area. The development of the tourist and recreational complex requires the establishment of improved mechanism to manage tourists' resources and the tourist sector in the Khanty-Mansiysky Autonomous Region - Yugra. However, management tool should ensure effective tourism growth as a cross-cutting sector integrating and growth-generating a few branches of the regional economy. [7]. In so doing, the tourism development as a significant sector for the territorial specialization at present is impossible by using functioning market-based mechanisms without State coordination and support as the catalyst for public-private partnership promotion. Public-private partnership should be observed as one of the main mechanisms to realize the Concept, it's the greatest opportunity to bring together government authorities and business representatives to create the most promising tourist sites and tourism service infrastructure for further development of internal and entrance tourism by means of the cluster approach. The cluster approach is characterized by a cross-industry approach, the concentration of enterprises and organizations concerned with the formulation, production, promotion and sale of the tourist products, related activities associated with tourism and recreational services in a limited area of land. In the tourist and recreational clusters development through using science-based decision-making and mechanisms of the public-private partnership the conditions for further tourism facilities and a sphere of accompanying services growth have been created.

Tourism promotion in the region is considered as one of the directions for revitalizing of social and economic advancement in the municipal sector. At some stage tourism services include new sectors: providing services for accommodation and catering, retail and wholesale distribution, souvenir products, transport services, etc. This let to contribute to create new employment opportunities, to make profits, indirectly influence the development related sectors. Tourism growth on the regional level facilitates ensuring recreational needs of the population (social factor), well-being of the population (economic factor), regional and municipal management (administrative factor), and recreational capacity (resource factor). Undoubtedly, the tourist and recreational complex may become one of the priority areas for municipalities developing and it lets significantly improve the quality of life and living standards of the local population. Introduction and development of the programme is one of the most effective ways to develop the sector in the Khanty-Mansiysky Autonomous Region - Yugra and creation of a more competitive market of tourism services, undertaking crucial goals of the social and economic regional development. Thus, the regional cultural policy is a certain level of the national cultural policy realization and introduction of various regional social-cultural programmes is the mechanism to implement the national policy on one hand. On the other hand, it's a policy area of its own to carry out project activities directed for comprehensive study and development of historical and cultural features, identity of every territory, identification and effective use of the regional resources (intellectual, financial, logistics conditions, etc.), design and implementation of regional programmes to support and develop the field of culture. Analysis of the problems, related to the formation of the regional cultural policy, modernization of the regional systems of management in the sphere of the culture has shown that they have the status of the complex socio-cultural phenomenon. The issue of the cultural policy is predicated by the unique nature of culture (not politics or economy), butmulti-levelled and polysemy of the meanings in the cultural content. This fact makes it the component of all areas of the state activity (economic, social, foreign policy, etc.) Just the nature of the culture has led to a requirement for the unity of standards and principles for functioning any subject in the area, particularly the state. In the context of new geopolitical conditions the mechanisms to implement the priorities of regions' development in Russia have been put, strategic and tactical scenarios are clearly defined. The results of the analysis of the quantitative estimates of the Nothern constituent entities' economic development in All-Russian context indicates about their relative wealth. In the conditions of the current expert resource-based economy these territories become the platform for innovation processes and that makes the Russian North different from other northern territories all over the world. 


\section{References}

Астафьева О.Н. Культурная политика: теоретическое понятие и управленческая деятельность / О.Н. Астафьева // Культурологический журнал = Journalofculturalresearch [Электронный ресурс]. 2011. № 2 .

Астафьева О.Н., Синецкий С.Б. Философские и прикладные аспекты культурной политики на поселенческом уровне // Вестник культуры и искусств. - 2017. - № 4 (52). - С. 74 - 75.

Жидков, В.С. Государственная культурная политика / В.С. Жидков // Ориентиры культурной политики, 2001. - № 6.

Концепция совершенствования региональной политики в Российской Федерации на период до 2020 года. Москва, 2011. [Электронный ресурс] Режим доступа: http://pandia.ru/text/77/224/22083.php

Михеева Н.А. Культурная политика государства как инструмент управления социально-культурной сферой / Н.А. Михеева // Электронное научное издание «Аналитика культурологии». 2006. - № 2 (6). - С.9 - 56.

Мурзина И. Я. Региональная культура как предмет философско-культурологического исследования / И.Я. Мурзина // Проблемы образования, науки и культуры. Вып. 15. № 30. 2004. - С.63- 98.

Постановление Правительства Ханты-Мансийского автономного округа - Югры от 1 июня 2012 года $\mathrm{n}$ 195-п «О концепции развития внутреннего и въездного туризма в Ханты-Мансийском автономном округе - Югре (в редакции постановлений правительства ХМАО - Югры от 07.02.2014 n 44-п, от 18.12.2015 n 472-п, от 03.03.2017 n 79-п)[Электронный ресурс] Режим доступа: http://docs.cntd.ru/document/468901176

Стратегия социально-экономического развития Ханты-Мансийского автономного округа до 2020 года и на период до 2030 года, утвержденная распоряжением Правительства Ханты-Мансийского автономного округа - Югры от 22 марта 2013 года N 101-рп [Электронный ресурс]Режим доступа: http://docs.cntd.ru/document/411709517

Стратегия развития культуры в Ханты-Мансийском автономном округе - Югре до 2020 года и на период до 2030 года»; Постановление правительства Ханты-Мансийского автономного округа - Югры от 9 октября 2013 г. n 427-п «О государственной программе Ханты-Мансийского автономного округа - Югры «Развитие культуры в Ханты-Мансийском автономном округе на 2018 - 2025 годы и на период до 2030 года» (в ред. Постановления правительства ХМАО - Югры от 02.03.2018 n 54-п) [Электронный ресурс]Режим доступа: http://base.garant.ru/18913384/53f89421bbdaf741eb2d1ecc4ddb4c33/

Флиер, А.Я. Культурология для культурологов /А.Я. Флиер. - Москва: Академический проект, 2000.

Хлыщева Е.В. Специфика региональной культуры / Е. В. Хлыщева // Фундаментальные проблемы культурологии: в 4 т. Санкт-Петербург, 2008. Том IV: Культурная политика. С. 146-158.

Целевая программа «Развитие культуры и туризма в Ханты-Мансийском автономном округе - Югре на 2016 - 2020 годы» [Электронный ресурс] Режим доступа: http: // www.tourism.admhmao.ru 